\title{
The Role of some Natural Enemies in Controlling the String Bean Pests in Greenhouse \\ Nawar, M. A. ${ }^{1}$ and Iman I. Imam ${ }^{2}$ \\ Animal Pest Unit ${ }^{1}$ and Econ. Entomol. Unit ${ }^{2}$, Plant Prot. Dept., Desert Res. Center
}

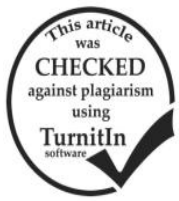

\section{ABSTRACT}

Bemisia tabaci Genn. (Hemiptera: Aleyrodidae) and Tetranychus urticae Koch. (Acari: Tetranychidae) are major pests infesting string bean, Green beans Phaseolus vulgaris, in greenhouses. The use of different release regimes of the two predators; Chrysoperla carnea (Steph.) (Neuroptera: Chrysopidae) and Amblyseius swirskii (Athias-Henriot) (Acari: phytoseiidae) was considered. The experimental desine included using either of $A$. swirskii or $C$. carnea solitary in sequential or combined release. Generally, the pests' populations decreased compaired with the control plants as result of predators release. The percent reduction of $T$. urticae and $B$. tabaci increased gradually to reach its maximum values (over $90 \%$ ) for $T$. urticae and $B$. tabaci, respectively after 8 to 10 weeks of release over different release regimsThe present study indicated that the use of $A$. swirskii or $C$. carnea for controlling both $T$. urticae and B. tabaci on $P$. vulgaris reveled similar effeciency regardless they were used soliratily or in combination under green housae conditions. So using either of them as avilable natureal enemy can be recommended.

\section{INTRODUCTION}

Green beans Phaseolus vulgaris, also known as the "common bean, string beans" belong to the family: Leguminosae (as shell beans, such as pinto beans, black beans and kidney beans). The main difference between green beans and other beans is they are eaten fresh and in their entirety rather than shelled and dried like many of their bean counterparts. Beans are one of the most important vegetable legumes exported in Egypt. It comes in second place after potatoes, although less than in production problems, which consume either fresh centuries or dry seeds. The bean crop is exposed to many pests. (Jones, et al., 1999). The whitefly, Bemisia tabaci Genn. (Hemiptera: Aleyrodidae), and the two spotted spider mite, Tetranychus urticae Koch. (Acari: Tetranychidae) are economically important pests in many ornamentals and vegetables grown in greenhouses and fields all over the world (Helle and Sabelis 1985; Lewis 1997; CAB International 2007 and Vincent et al., 2007). B. tabaci poses a serious threat to the greenhouse vegetable industry because of its resistance to many pesticides, and as an efficient vector for numerous plant viruses (Gerling 1990). The two-spotted spider mite, $T$. urticae Koch is one of the most serious agricultural pests in the world. This mite is polyphagous and attacks the broad range of crops, including cowpea and common bean and etc. (Van de Rrie et al., 1972; Khanjani, 2005). Chrysoperla carnea Stiph. (Neuroptera: Chrysopidae) known as the common aphid lion. Adults feed on nectar, pollen and aphid's honeydew. They are not predatory, but the larvae are active predators and feed on aphids and other small insects. It has been used in the biological control of insect pests on crops (Raphaela and Elisabeth 2012). Predators are expected to attracte more profit table plants (i.e. plants occupied by herbivores that represent food for their development and reproduction (Venzon et al., 2002). Amblyseius swirskii Athias-Henriot (Acari: Phytoseiidae) is an effective predator feeding and biological control agent against different insect and mite pests such as whiteflies, thrips and two-spotted spider mites (Nomikou et al. 2001 and Soleymani et al., 2016). A. swirskii, is a biological control agent of Tetranychus urticae Koch., a key-pest of strawberry (Oliveira et al., 2007). The diet of phytoseiid mites may include several whitefly and mite species as well as pollen (Nawar and El-Sheriff,1993 ; McMurtry and Croft, 1997; Abou- Awad et al.,1998; El-Banhawy et al., 2000).
The presence of $B$. tabaci on the host plant reduced predation of two-spotted spider mites by Cydnoseius negevi (right) while increasing the predator's reproduction, suggesting higher quality of a mixed diet over twospotted spider mites alone (El-Banhawy et al.,1999). A. swirskii and Euseius scutalis (Athias-Henriot), appear to be promising biological control agents against $B$. tabaci based on their high intrinsic rates of increase in the laboratory (Nomikou et al., 2001) and their ability to suppress whitefly populations on isolated plants in a greenhouse (Nomikou, person al communication).

This study amed at applying available control methods individually or collectively in a single program to maximizes their role in reducing pest numbers and most importantly, reducing the chances of environmental pollution.

\section{MATERIALS AND METHODS}

This study on the prey-predator relationships was conducted in a greenhouse of the plant protection department at the Desert Research Center.

1-Origin and maintenance of arthropod cultures:

a- Insects and mites:

A. swirskii, B. tabaci and T. urticae were colleted from infested plants in a commercial plantation in Salhiya City, They were reared on the underside of detached common bean leaves, $P$. vulgaris, which were put on top of a moist sponge placed inside a box (35 $\mathrm{x}$ $115 \times 115 \mathrm{~mm}$ ). The edges of the leaves were surrounded by moistened cotton to prevent mite from escaping. The leaves were replaced when its turgidity was severely reduced. The rearing units were kept at $25^{\circ} \mathrm{C}$.

\section{b- Tested insect:}

The predator, C. carnea was initially collected from the cotton field and reared on angoumois grain moth, Sitotroga cerealella (Olivier) eggs at the same mentioned laboratory conditions. The adults of $C$. carnea were sexed and 10 pairs of adults were placed in plastic boxes $(22 \times 13 \times 10 \mathrm{~cm})$ covered with black muslin for deposited eggs and changed daily. Drops of semi artificial diet solution consists of $2 \mathrm{~g}$ yeast extract, $1 \mathrm{~g}$ fructose and $1 \mathrm{ml}$ distilled water were provided on tape stacked on the muslin cover. The deposited eggs were collected daily and kept in glass jars until hatching. The hatched larvae were reared on $S$. cerealella eggs. (Hassan and Ezz 2009). 


\section{2- Experimental design}

Experiment on the prey-predator relationships was conducted in a greenhouse using potted bean plants. The plants in 90 pots (three per pot), were grown in 15.0 $\mathrm{cm}$ using clay and sand. Fifteen days after the plants sprouted; three or four females of T. urticae, ten adults of $B$. tabaci were placed on each pot. Five days later, three leaves were removed from each plant to determine if the population of $T$. urticae, has increased sufficiently to warrant liberation of $A$. swirskii.

Pots were divided into 6 groups:

1 - Release predator $A$. swirskii

2 - Release predator $C$. carnea

3 - Release of C. carnea followed by A. swirskii

4- Release of A. swirskii followed by C. carnea

5- Release of A. swirskii and C. carnea at the same time 6- Control (no predators)

When the population counts were sufficiently high, three adults of A. swirskii and C. carnea $\left(2^{\text {nd }}\right.$ instar larvae) were placed on pot of the plants. The released plant plots were separated from each other by plastic sheet to avoid the predator escaping to other plots. Infasted bean leaves with the predatory mite were transferred in ice-box to the greenhouse and then releasd on infested peen plants. After one week of relasing, 30 leaves were taken weekly, placed in paper bags and transferred to the laboratory. Motile stages prey were counted on three randomized chosen inches ${ }^{2}$ for 12 subsquent weeks.

Percent reduction was calculted as percent diffrefce between the count in control and the treatment divided by the count on control.

Statistical analysis

Date were analyzed using SAS Program and means separated by the L.S.D test (SAS Institut, 1988).

\section{RESULTS AND DISCUSSION}

Obtained results are presented in Tables (1,2 and 3). The mean number of motile stages of the two spotted spider mites and B. tabaci was recorded before the predators relese was 25.17 and 23.17individuals per leaf, respecatly (Table 1).

Release of A. swirskii only one week after releasing the predator, the population of T. urticae and B. tabaci decreased slightly with average of $22.6+2.3$, $33.6+2.7, \quad 25.6+3.8$ and $37.2+4.9$ for the different treatment,and control, respectively. Concerning the weekly mean reduction of all stages of the predatory mite 11 and $10 \%$, individuals in the two treatments, were recorded respectively.

The percent reduction of $T$. urticae and B. tabaci increased gradually to reach its maximum values (i.e. 97 , 100,87 to and $76,93,68 \%$ to for T. urticae and B. tabaci, respectively) after 8 to 10 weeks of release (Table 1).

Table 1. Effect of the release of $A$. swirskii and $C$. carnea for reducing the population of $T$. urticae and $B$. tabaci infesting bean (Phaseolus vulgaris) plant under green house

\begin{tabular}{|c|c|c|c|c|c|c|c|c|}
\hline \multirow{3}{*}{$\begin{array}{l}\text { Predator } \\
\text { Sampling }\end{array}$} & \multicolumn{4}{|c|}{ A. swirskii } & \multicolumn{4}{|c|}{ C. carnea } \\
\hline & \multicolumn{2}{|c|}{ T. urticae } & \multicolumn{2}{|c|}{ B. tabaci } & \multicolumn{2}{|c|}{ T. urticae } & \multicolumn{2}{|c|}{ B. tabaci } \\
\hline & Mean & Reduction & Mean & Reduction & Mean & Reduction & Mean & Reduction \\
\hline 1 & $24.20+3.7$ & - & $28.00+5.6$ & - & $24.60+4.67$ & - & $22.20+0.8$ & - \\
\hline 2 & $22.6+2.3$ & 11 & $33.60+2.7$ & 10 & $22.80+3.1$ & 11 & $32.60+7.6$ & 12 \\
\hline 3 & $18.8+1.6$ & 23 & $33.6+5.4$ & 21 & $20.40+1.9$ & 17 & $27.6+5.2$ & 35 \\
\hline 4 & $20.0+2.2$ & 43 & $27.2+5.5$ & 45 & $24.2+3.2$ & 32 & $25.0+4.6$ & 50 \\
\hline 5 & $16.2+2.1$ & 62 & $28.2+5.5$ & 52 & $22.8+3.1$ & 47 & $18.4+4.5$ & 68 \\
\hline 6 & $11.6+4.5$ & 78 & $21.8+5.1$ & 59 & $19.2+6.8$ & 63 & $24.6+4.6$ & 53 \\
\hline 7 & $4.4+1.1$ & 89 & $20.8+5.7$ & 63 & $6.8+4.1$ & 84 & $15.8+4.8$ & 72 \\
\hline 8 & $0.60+0.9$ & 97 & $9.4+6.0$ & 76 & $1.4+2.6$ & 93 & $3.0+2.8$ & 92 \\
\hline 9 & 0 & 100 & $2.4+3.7$ & 93 & $0.6+0.5$ & 96 & $0.20+0.45$ & 99 \\
\hline 10 & $1.6+2.1$ & 87 & $15.6+6.3$ & 68 & $0.4+0.4$ & 96 & $1.4+1.5$ & 97 \\
\hline
\end{tabular}

Obtaind data agree with those of Heikal and Ibrahim (2001) on strawberry. However, Mowafi (2005) repoted that, the releasing the prdtoatory mite, $P$. macroplils on cucumber indicated the possibility of controlling $T$. urticae in the the greenhouses by applying only one release of the predator early when the pest population is low.

\section{Relase of $C$. carnea only}

The percent reduction of $T$. urticae and B. tabaci increased gradually to reach its maximum values (i.e. 93, 96, 96 to and $92,99,97 \%$ to for $T$. urticae and $B$. tabaci, respectively) after 8 to 10 weeks of release (Table 1)

Mean percent reduction was (96 and 99\%), as result of releasing $C$. carnea to control T. urticae and nymphs of whitefly on cucmber plants (Butler and Hungerford 1971).

\section{Sequintial sequential release}

The percent reduction of $T$. urticae and $B$. tabaci as result of releasing $C$. carnea followed by $A$. swirskii increased gradually to reach its maximum values (i.e. $88,100,98$ and $88,90,96 \%$ to for $T$. urticae and $B$. tabaci, respectively) after 8 to 10 weeks of release. Percent reduction of $T$. urticae and $B$. tabaci as result of releasing $A$. swirskii followed by $C$. carnea increased gradually to reach its maximum values (i.e. $75,87,89$ to and $71,91,96 \%$ for $T$. urticae and B. tabaci, respectively) after 8 to 10 weeks of release (Table 2). $C$ carnea sometimes doses not discriminate between the mites and other pestes (Canard and Duelli1984). 
Table 2. Effect of the release of A. swirskii and C. carnea for reducing the population of T. urticae and B. tabaci infesting bean (Phaseolus vulgaris) plant under green house

\begin{tabular}{lcccccccc}
\hline \multirow{2}{*}{$\begin{array}{l}\text { Predator } \\
\text { Sampling }\end{array}$} & \multicolumn{3}{c}{ C. carnea then $\boldsymbol{A}$. swirskii } & \multicolumn{3}{c}{ A. swirskii then C. carnea } \\
\cline { 2 - 9 } & \multicolumn{2}{c}{$\boldsymbol{T}$. urticae } & \multicolumn{2}{c}{ B. tabaci } & \multicolumn{2}{c}{ T. urticae } & \multicolumn{2}{c}{ B. tabaci } \\
\hline 1 & $23.60+4.2$ & - & $20.20+1.9$ & - & $25.60+3.3$ & - & $20.20+3.3$ & - \\
2 & $20.20+1.6$ & 21 & $30.0+4.1$ & 19 & $22.60+2.8$ & 8 & $34.0+1.6$ & 8 \\
3 & $19.80+7.0$ & 19 & $28.40+6.3$ & 33 & $17.20+3.2$ & 30 & $31.0+6.7$ & 28 \\
4 & $25.0+5.0$ & 29 & $20.4+7.8$ & 59 & $23.8+4.4$ & 33 & $17.8+2.4$ & 64 \\
5 & $16.4+5.0$ & 62 & $33.4+7.8$ & 43 & $19.2+4.4$ & 55 & $25.8+2.3$ & 56 \\
6 & $16.2+2.7$ & 69 & $36.2+4.5$ & 32 & $12.6+2.7$ & 76 & $36.6+4.3$ & 31 \\
7 & $6.4+1.1$ & 85 & $17.2+2.7$ & 70 & $8.0+2.1$ & 81 & $16.0+3.8$ & 72 \\
8 & $2.6+1.1$ & 88 & $4.8+2.4$ & 88 & $5.6+2.6$ & 75 & $11.4+6.3$ & 71 \\
9 & 0 & 100 & $3.4+1.1$ & 90 & $2.0+0.7$ & 87 & $3.0+0.7$ & 91 \\
10 & $0.8+1.1$ & 93 & $2.0+1.0$ & 96 & $1.4+0.5$ & 89 & $1.6+1.1$ & 96 \\
\hline
\end{tabular}

Combined release

The percent reduction of $T$. urticae and $B$. tabaci as result of combined release of $C$. carnea and A. swirskii at yhe same time increased gradually to reach its maximum values (i.e. 84, 98, 96 and 84, 87, 92, respectively). Younes et al., (2013) found that the 2nd larval instar of $C$. carnea reduced the population of the whitefly by $(83.07 \%)$ under semi-field conditions on cantaloupe. $P$. persimilis proved to be sufficiently effective against $T$. urticae under greenhouse conditions in Egypt (Rasmy and Ellaithy, 1988). Adly (2015) evaluated the combination of the releases of the parasitoid, Aphidius colemani Viereck against aphids; the predators of $C$. carnea against the aphids and the whitefly and of $P$. persimilis against $T$. urticae.

Table 3. Effect of the release of $A$. swirskii and $C$. carnea at the same time for reducing the population of $T$. urticae and $B$. tabaci infesting bean (Phaseolus vulgaris) plant under green house.

\begin{tabular}{lcccccc}
\hline \multirow{2}{*}{$\begin{array}{l}\text { Predator } \\
\text { Sampling }\end{array}$} & \multicolumn{3}{c}{$\boldsymbol{A}$. swirskii and $\boldsymbol{C}$. carnea at the same time } & \multicolumn{2}{c}{ Control } \\
\cline { 2 - 7 } & Mean & Reduction & Mean & Reduction & Mean & Mean \\
\hline 1 & $28.20+3.8$ & - & $18.40+4.2$ & - & $24.20+3.9$ & $31.0+4.9$ \\
2 & $22.00+1.5$ & 14 & $33.40+1.1$ & 10 & $25.6+3.8$ & $37.2+4.9$ \\
3 & $21.40+1.8$ & 13 & $30.0+6.2$ & 30 & $24.6+3.8$ & $43.0+5.4$ \\
4 & $23.4+2.6$ & 34 & $26.8+5.3$ & 46 & $35.6+4.0$ & $49.8+5.7$ \\
5 & $21.8+2.5$ & 50 & $29.6+5.2$ & 49 & $43.6+4.0$ & $59.0+5.7$ \\
6 & $17.0+3.3$ & 68 & $27.2+3.5$ & 49 & $53.2+4.8$ & $53.4+2.1$ \\
7 & $7.0+1.0$ & 83 & 22.20 & 61 & $43.2+3.1$ & $57.4+8.8$ \\
8 & $3.6+1.1$ & 84 & $6.4+1.6$ & 84 & $22.8+3.9$ & $40.0+8.9$ \\
9 & $0.2+0.45$ & 98 & $4.2+1.3$ & 87 & $15.6+1.5$ & $34.6+6.2$ \\
10 & $0.4+0.5$ & 96 & $3.8+0.8$ & 92 & $12.6+2.9$ & $49.4+6.5$ \\
\hline
\end{tabular}

Statistical analysis

Statistical analysis of obtained reduction dataindicated no significant diferrences between tested predators or sequance of release $(\mathrm{F}$ value $=1.67, \mathrm{P}$ value $=$ $0.1817, \mathrm{LSD}=5.7924$ for T. urticae and $\mathrm{F}$ value $=2.02, \mathrm{P}$ value $=0.1158, \mathrm{LSD}=7.666$ for $B$. tabaci ).

\section{CONCLUSION}

The present study indicated that the use of $A$. swirskii or C. carnea for controlling both $T$. urticae and $B$. tabaci on $P$. vulgaris reveled similar effeciency regardless they were used soliratily or in compination under green housae conditions. So using either of them as avilable natureal enemy can be recommended.

\section{REFERENCES}

Abou-Awad, B. A., El-Sherif, A. A., Hassan, M. F., AbouEleila, M. M., (1998). Studies on development ,longevity, fecundity and predation of Amblyseius olivi Nasr \& Abou-Awad (Acari: Phytoseiidae) on various kinds of prey and diets. Z. Pflanzenkr. Pflanzenschutz 105, 538-544.
Adly, D. (2015). Comparative study of biological and chemical control programs of certain cucumber pests in greenhouses. Egypt. J. Biol. Pest Cont. 25(3): 691-696. Proceeding of 4th International Conference, ESBCP, Cairo, Egypt, 19-22 October 2015.

Butler, G. D., and Hungerford, C. M. (1971). Timing filed releases of eggs and larvae of Chrysopa carnea to insure survival.J.Econ. Entomol. 64,311-312.

CAB International. 2007. Animal Health and Production Compendium. CAB International.

CAB nternational/AAFC 432p. Chapter 12 Biological Control of Insect Pests in Greenhouses: an Unexpected Success. JOOP C. VAN LENTEREN 105-117. ISBN-13: 978 1845932657.

Canard, M., and P. Duelli. (1984). Predatory behavior of larvae and cannibalism. Pages $92-100$ in $\mathrm{M}$. Canard, Y. Se'me'ria, and T. R. New, editors. Biology of Chrysopidae. Dr. W. Junk, The Hague, The Netherlands 
El-Banhawy, E. M., Hafez, S. M., Saber, S. A., (1999). Effect of the nymph prey density of the two spotted spider mite Tetranychus urticae Koch (Acari: Phytoseiidae) on the consumption and reproduction rates of the predacious mite Cydnoseius negevi (Swirski \& Amitai) in absence and presence of nymphs of the white fly Bemisia tabaci (Genn.). Anz. Schaedlingskd. Pflanzenschutz 72,55-56.

El-Banhawy, E.M., Amer, S.A.A., Saber, S.A., (2000). Development and reproduction of the predacious mite, Amblyseius cydnodactylon on different prey species; effect of plant leaf texture on the behaviour and reproduction of the predator. Z. Pflanzenkr. Pflanzenschutz 107,218-224.

Gerling, D. 1990. Natural enemies of whiteflies: Predators and parasitoids. In "Whiteflies: Their Bionomics, Pest Status and Management"' (D. Gerling, Ed.), pp. 147-185. Intercept, Andover, UK.

Hassan, K. A. and Nahla A. Ezz (2009): Inpact of the entomopathogenic fungus Beauveria bassiana(Bals.) vuill on the predator Chrysopela carnea (Stephens) (Neuroptera: Chrysopidae).,Bull. Ent. Soc. Egypt, Econ.Ser, 35: 9-17.

Heikal, J.H. and G.A. Ibrahim (2001):Release of phyroseiuls macropilis (Banks) control Tetranychus urticae kch on strawberry in ismiaila Govermoate- egypt (Acari phytosieiidu\&Tetraychidae) Egypt. J. Agric. Res. 79(3):893-906.

Helle W, Sabelis MW. 1985. Spider mites.Their biology, natural enemies and control. Elsevier.

Jones A.L., Danilo Mejia, and Beverly Lewis (1999): Phaseolus bean: Post-harvest Operations. Centro Internacional de Agricultura Tropical (CIAT).

Khanjani, M. (2005). Field crop pests (insects and mites) in Iran. Abu-Ali Sina University Press, Hamadan, Iran. (In Persian).

Lewis T. 1997. Thrips as Crop Pests. London: CAB International.

McMurtry,J.A., Croft,B.A., (1997). Life-styles of phytoseiid mites and their roles in biological control. Annu. Rev. Entomol. 42, 291-321.

Mowafi MH (2005). Release of the predacious mite Phytoseiulus macropilis (Banks) to control Tetranychus urticae Koch (Acari: Phytoseiidae and Tetranychidae) in a cucumber greenhouse. Egyptian J. Biol. Pest Cont., 15(1/2): 109-111.
Nawar, M.S.,El-Sherif,A.A., (1993). Neoseiulus cucumeris (Oudemans), a predator of whitefly Bemisia tabaci (Gennadius). Bull. Entomol. Soc. Egypt 71,9-17.

Nomikou, M., Janssen, A., Schraag, R., Sabelis, M. W., (2001). Phytoseiid predators as potential biological control agents for Bemisia tabaci. Exp. Appl. Acarol. 25,271-291 .

Oliveira H, Janssen A, Pallini A, Venzon M, Fadini M A M, Duarte V (2007) A phytoseiid predator from the tropics as potential biological control agent for the spider mite Tetranychus urticae Koch (Acari: Tetranychidae). Biol Control 42: 105-109.

Raphaela Bantz and Elisabeth Stölzel (2012): Biology of the green lacewing Chrysoperla carnea and its use in biological control, Applied Entomology in orchards, vineyards and horticultural crops (935.102).

Rasmy, A. H. and Ellaithy A. Y. M. (1988). Introduction of Phytoseiulus persimilis for two spotted spider mite control in greenhouses in Egypt [Acari: Phytoseiidae, Tetranychidae]. Entomophaga, 33(4): 435-438.

SAS Institute (1988): SAS user's guide: Statistics. SAS Institute, Cary, N.C.

Soleymani H, Hakimitabar Mas and Marjan S (2016) Prey preference of predatory mite Amblyseius swirskii (Acari: Phytoseiidae) on Tetranychus urticae (Acari: Tetranychidae) and Bemisia tabaci (Hemiptera: Aleyrodidae) Biocontrol Science and Technology 26 (4), p. 562

Van de Rive, J. A. C., Murtry, J. A., Huffaker, C. B. (1972): Ecology of mites and their natural enemies. A review. III Biology, ecology, and pest status, and host plant relations of Tetranychids. Hilgardia, 41: 354-432.

Venzon M, Janssen A, Sabelis M W (2002) Prey preference and reproductive success of the generalist predator Orius laevigatus. Oikos 97:116-124.

Vincent, C., Goettel, M. S. and Lazarovits, G. 2007. Biological control: A global perspective.

Younes, M. W. F., Shoukry, I. F., Metwally, S. A. A. G. and Abd-Allah, Y. N. M. (2013). Efficiency of second instar larvae of Chrysoperla carnea to suppress some piercing sucking insects infesting cantaloupe under semi-field conditions. Egypt. J. Agric. Res., 91 (1): 169- 179.

\section{دور بعض المفترسات الحيوية في مكافحة افات الفاصوليا تحت ظروف الصوبة

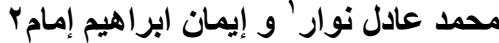 وحدة الافات الحيوانية' ، حدة الحشرات الاقتصادية' ـ قسم وقاية النبات ـ مركز بحوث الصحراء}

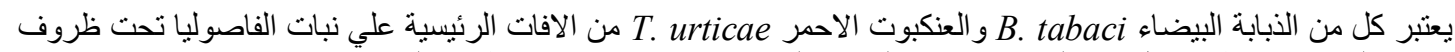

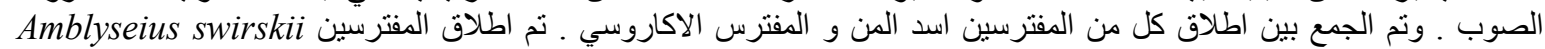

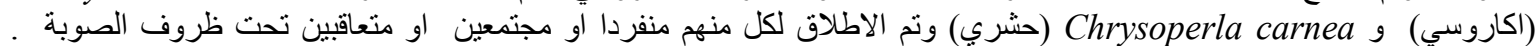

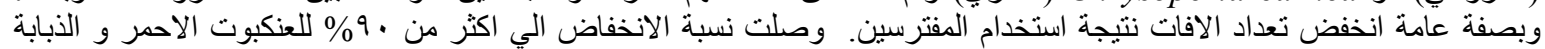

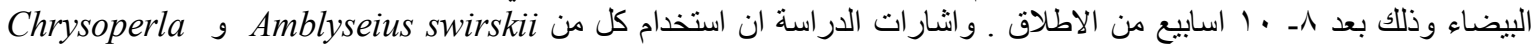
carnea

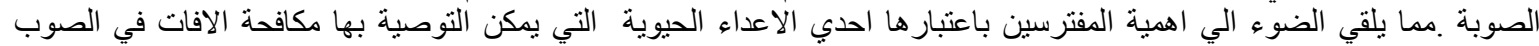

